\title{
ПРОБЛЕМИ ГЕНДЕРНОГО ПАРИТЕТУ У ВИЩІЙ МЕДИЧНІЙ ОСВІТІ
}

\author{
В. М. Мороз, Ю. Й. Гумінський, Л. В. Фоміна \\ Вінницький національний медичний університет імені М. I. Пирогова
}

\section{PROBLEMS OF GENDER PARITY IN HIGHER MEDICAL EDUCATION}

\author{
V. M. Moroz, Yu. Y. Huminskyi, L. V. Fomina \\ Vinnytsia National Medical University by M. I. Pyrohov
}

\begin{abstract}
У статті узагальнено та проаналізовано матеріал з питань гендерного підходу у вищій медичній освіті. Враховуючи чинне національне законодавство та світовий досвід 3 питань гендерного паритету, автори висвітлюють реалізацію принципів рівності між учасниками освітнього процесу та окреслюють тенденції у набутті професійної кваліфікації 3 огляду на гендерний аспект.
\end{abstract}

The article generalizes and analyzes the material on gender approach in higher medical education. Taking into account a current national legislation and world experience on gender parity, authors light up the realization of principles of equality between the participants of educational process and outline tendencies in acquisition of professional qualification, considering the gender aspect.

Вступ. Стабільний розвиток українського суспільства багато в чому залежить від реалізації принципів гендерного паритету: подолання соціальноекономічних та політичних негараздів як для жінок, так і для чоловіків є індикатором сталого розвитку країни. Гендерна складова, яка безпосередньо пов’ язана з людським потенціалом, є однією з найважливіших у Європейському Союзі, і такою має стати в Україні, яка прагне цивілізаційного прогресу.

Питання формування та реалізації принципів гендерної рівності були предметом аналізу багатьох дослідників (Г. Герасименко, Л. Гонюкова, О. Грішнова, Г. Даудова, К. Карпенко, І. Когут, Н. Лавриненко, І. Лазар, К. Левченко, С. Оксамитна, В. Сичова та інші). Однак для з’ясування причин того чи іншого соціального факту в освітній галузі потрібні подальші дослідження.

Мета статті полягає в аналізі стану гендерного паритету у Вінницькому національному медичному університеті імені М. І. Пирогова та в обгрунтуванні на основі чинного національного законодавства і світового досвіду рівноправної участі чоловіків та жінок в освітньому процесі з метою підвищення професійної кваліфікації у вищому медичному закладі освіти.

Основна частина. Гендерний аспект визначає становище чоловіка та жінки у суспільстві, адже

( В. М. Мороз, Ю. Й. Гумінський, Л. В. Фоміна жінка і чоловік - дві половинки людства, і від того, як формуються відносини між ними, залежить, якої форми набудуть усі інші людські відносини. Рівноправна участь жінок і чоловіків у всіх сферах життєдіяльності суспільства та держави є важливою умовою й гарантією забезпечення прав людини, запорукою європейської демократичної інтеграції країни. Формування та регулювання державної політики України з утвердження гендерної рівності здійснюється відповідно до міжнародних зобов’ язань і національного законодавства. Україна 1980 року ратифікувала Конвенцію ООН “Про ліквідацію всіх форм дискримінації щодо жінок” [4], чим підтвердила необхідність втілення у життя ідей рівноправ'я між жінками і чоловіками в усіх сферах соціально-економічного, політичного, освітньо-культурного життя.

У статті 24 Конституції України (1996) проголошується гендерна рівність конституційних прав та свобод жінок і чоловіків, підкреслюється, що “громадяни мають рівні конституційні права і свободи та $є$ рівними перед законом. Не може бути привілеїв чи обмежень за ознаками раси, кольору шкіри, політичних, релігійних та інших переконань, статі, етнічного та соціального походження, майнового стану, місця проживання, за мовними або іншими ознаками” [1]. Інтегрування гендерного підходу в національний освітній простір закріплюється чинною законодавчою базою. Прийнятий 1991 року 
Закон України “Про освіту” проголосив метою освіти “вільний розвиток людської особистості”, яка вважається найвищою цінністю суспільства. Закон України “Про освіту” має згадку про забезпечення гендерної рівності - у статті 3 “Право громадян України на освіту” зазначено, що “громадяни України мають право на безкоштовну освіту в усіх державних навчальних закладах незалежно від статі, раси, національності, соціального і майнового стану, роду та характеру занять, світоглядних переконань, належності до партій, ставлення до релігії, віросповідання, стану здоров’ я, місця проживання та інших обставин” [2].

Як бачимо, чинне законодавство України принципово не суперечить нормам міжнародно-правових актів. Воно надає жінкам однакову з чоловіками громадську правоздатність й однакові можливості їі реалізації, а також за порушення цивільно-правових норм встановлює однакову відповідальність.

3 проголошенням Україною курсу на європейську інтеграцію гендерне питання набуває особливого значення в освітніх процесах нашої держави. Дотримання гендерних стандартів є не лише яскравим показником демократизації суспільства, а й необхідною умовою для вступу в Європейське співтовариство.

Цікавим, на нашу думку, є дослідження участі чоловіків та жінок в освітньому процесі вищої медичної школи по Україні. Загалом, у вищій освіті кількість чоловіків та жінок, за даними статистики 2014 року, є співмірною - зі 158,5 тис. викладачів ВНЗ III-IV ступенів жінки складають 52,4 \%. Але при цьому на спеціальностях гуманітарних напрямів - до 80 \%, а на інженерних - 24 \%. Переважно “жіночими” є напрями освіти та сфери обслуговування - по 69 \%, а от серед тих, хто вивчає військові науки, жінок лише 5 \% [5].

Попри те, що освіта є однією з найбільш фемінізованих галузей, серед ректорів ВНЗ III-IV рівнів акредитації державної та комунальної форм власності, яких в Україні налічується 234, усього 20 жінок (9 \%) від загальної кількості керівників таких ВНЗ. Нещодавно (вдруге за всю його історію і вперше з 1936 року) жінка очолила Національний медичний університет ім. О. О. Богомольця [5].

Враховуючи сказане, ми закцентуємо увагу на навчально-освітньому процесі з огляду на гендерний підхід у Вінницькому національному медичному університеті імені М. І. Пирогова і покажемо реалізацію принципів рівності між учасниками освітнього процесу, незалежно від їх походження, матеріальних статків, національності, громадянства, віросповідання чи статі.

Серед контингенту студентів частка жінок і чоловіків за спеціальностями є різною. Так, серед 7976 студентів усіх форм навчання (крім тих, хто перебуває в академічній відпустці) жінок - 4833 (60,6 \%), а чоловіків, відповідно, 3143 (39,4 \%). Проте по факультетах кількісні показники нерівномірні. Якщо на спеціальності “Стоматологія” за статтю навчається відносно рівна кількість студентів (47,6 \% чоловіків та 52,4 \% жінок), то за напрямами “Лікувальна справа” та “Педіатрія” дві третіх це жінки. Ще більш жіночими є спеціальності "Медична психологія”: перевага жінок тут очевидна 82,5 \%, “Фармація” - 86,5 \% та “Клінічна фармація” - 87,2 \%. Серед студентів-іноземців картина протилежна: серед 1786 осіб лише 579 (32,4%) жінок (рис. 1).

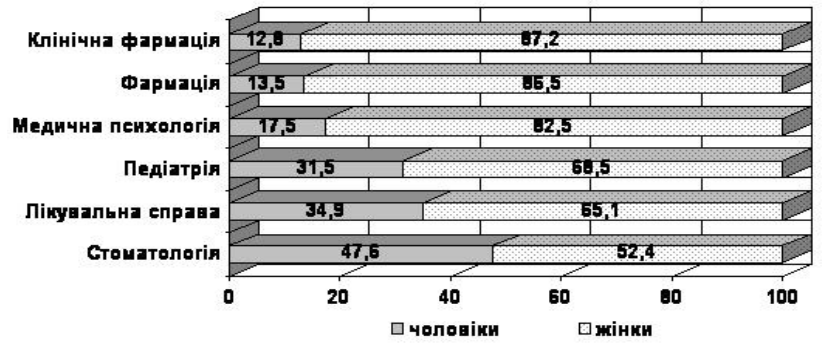

Рис. 1. Контингент студентів за спеціальностями і статтю.

Отже, на початку здобуття професійної кваліфікації бачимо переважну більшість жінок.

Висвітлимо гендерний аспект серед контингенту осіб, що підвищують кваліфікацію у ВНМУ ім. M. I. Пирогова, на факультеті післядипломної освіти та у навчально-наукових підрозділах університету (табл. 1). У цілому частка жінок складає 68,0 \%, а чоловіків, відповідно, - 32,0 \%. На кожній сходинці підвищення кваліфікації кількісно переважають жінки, проте на найвищому рівні докторанти - все ж чоловіків більше.

Крім горизонтального, в українській вищій школі присутній також і вертикальний поділ людей за відмінністю соціального статусу, зокрема, у сфері вищої медичної освіти, тобто спостерігається зменшення частки жінок на вищих професійних щаблях, причому це стосується як адміністративної сфери, так і науково-викладацької. Сьогодні в університеті всього працює 1669 співробітників, з яких 55,8 \% жінок і 44,2 \% чоловіків. Проте до складу ректорату ВНМУ ім. М. І. Пирогова входять лише 12 жінок, тобто 30,7 \%, а серед 56 завідувачів кафедр - 18 
Таблиця 1. Гендерний аналіз контингенту, що підвищує кваліфікацію, станом на 01.01.2015 р.

\begin{tabular}{|l|c|c|c|c|c|c|}
\hline $\begin{array}{c}\text { Контингент ВНМУ } \\
\text { ім. М. І. Пирогова }\end{array}$ & Чоловіки, осіб & $\%$ & Жінки, осіб & $\%$ & Всього, осіб & Всього, \% \\
\hline Магістранти & 15 & 30,6 & 34 & 69,4 & 49 & 100,0 \\
\hline Лікарі-інтерни & 343 & 30,2 & 792 & 69,8 & 1135 & 100,0 \\
\hline Клінічні ординатори & 28 & 49,1 & 29 & 50,9 & 57 & 100,0 \\
\hline Аспіранти & 42 & 42,0 & 58 & 58,0 & 100 & 100,0 \\
\hline Докторанти & 2 & 66,7 & 1 & 33,3 & 3 & 100,0 \\
\hline
\end{tabular}

жінок (32,1 \%). Отже, менше третини жінок належить до керівного складу університету. Здебільшого жінки працюють у наукових структурах, відділах, громадських, адміністративно-господарських та допоміжних структурних підрозділах, які є менш престижними і, відповідно, менш оплачуваними, адже здобуття наукових ступенів та вчених звань, що $є$ основними кроками у викладацькій кар’єрі, супроводжується зменшенням частки жінок на кожному наступному щаблі академічної кар’єри (рис. 2).

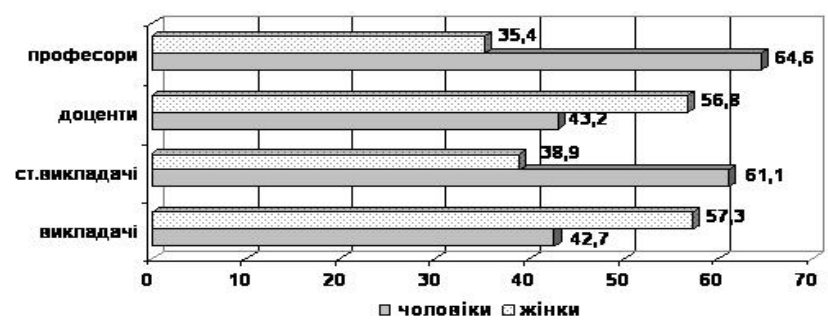

Рис. 2. Частка чоловіків і жінок в академічній кар’єрі BHMУ.

Викладачами і старшими викладачами кафедр працюють 406 осіб, з них 229 жінок, що становить 56,4 \%. Схожа картина і зі здобуттям вченого звання: звання доцента мають 375 осіб, з них жінок - 213 (56,8 \%), але є відчутна різниця у званні професора: серед 96 осіб лише 34 жінки, тобто тільки третина жінок працює на посаді професора або мають це вчене звання.

Якщо розглянути питання здобуття наукових ступенів, то слід зауважити, що серед 600 кандидатів наук ВНМУ імені М. І. Пирогова спостерігається відносна кількісна перевага жінок: вони складають 349 осіб (58,2 \%), а чоловіки - 251 особа (41,8 \%). Проте зовсім інші цифри маємо серед 118 докторів наук: частка жінок складає 33,1 \% (39 осіб), відповідно, частка чоловіків становить 66,9 \% (79 осіб) (рис. 3).

Згідно з новою редакцією Закону України “Про вищу освіту” (ст. 59) науково-педагогічним, науковим і педагогічним працівникам вищих навчальних закладів встановлюються доплати за науковий ступінь доктора філософії та доктора наук у розмірах,

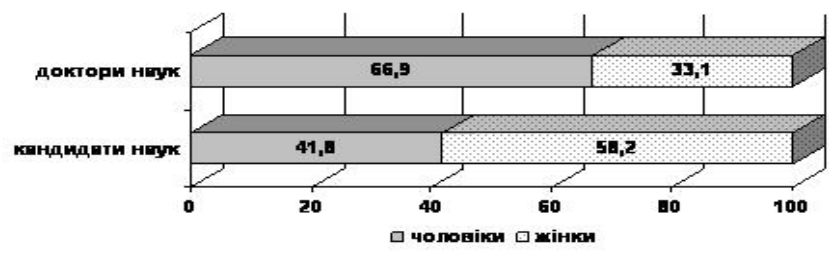

Рис. 3. Розподіл науково-педагогічних працівників за науковими ступенями і статтю.

відповідно, 15 та 20 відсотків посадового окладу, а також за вчене звання доцента і старшого дослідника - 25 \% посадового окладу, професора - 33 \% посадового окладу (з 01.01.2018 р. - прим. авторів) [3]. Відповідно відрізнятимуться і доходи науковопедагогічних працівників за гендерною ознакою, адже кількість професорів та докторів наук - чоловіків - значно більша, ніж жінок.

Серед 25 осіб професорсько-викладацького складу та наукових співробітників ВНМУ імені М. І. Пирогова, які мають почесні звання (заслуженого діяча науки та техніки України, заслуженого працівника освіти України, заслуженого лікаря (фармацевта) України), жінок 7, що у відсотковому відношенні становить 28,0 \%.

Лікарські категорії мають 636 науково-педагогічних працівників ВНМУ ім. М. І. Пирогова, 3 них 238 осіб мають вищу кваліфікаційну категорію, тобто мають стаж роботи не менше 10 років; мають високу теоретичну та практичну професійну підготовку згідно з програмою; володіють сучасними методами профілактики, діагностики і лікування хворих за своєю та суміжними спеціальностями. Частка науковопедагогічних працівників - жінок, що мають категорію, складає 196 осіб, а вищу кваліфікаційну категорію мають 106 жінок. Отже, у цьому плані спостерігається відносний гендерний паритет (рис. 4).

Функціонування інституту освіти у стабільному суспільстві помітно відрізняється від його функціонування у суспільстві з перехідною динамікою розвитку, як сьогодні в Україні. До того ж, якщо наприкінці XIX століття жінка-викладач у вищій школі була поодинокою постаттю, то на початку XXI століття ці професії, схоже, перетворюються на ти- 


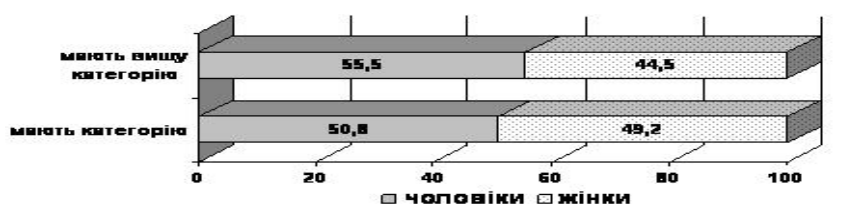

Рис. 4. Розподіл професорсько-викладацького колективу за лікарськими категоріями і статтю.

пові жіночі. Крім основного науково-педагогічного навантаження, професорсько-викладацький колектив постійно працює над сучасними інноваційними розробками, які мають велике фундаментальне та прикладне значення для подальшого розвитку медико-освітньої галузі. Провідну роль у цьому процесі відіграють не біологічні чинники, а соціальнокультурні та суспільні ролі кожного члена колективу. Здійснювати наукові відкриття не є беззаперечним правом чоловіка чи жінки, а, насамперед, правом обдарованості, таланту, навіть геніальності. Як сказав Людвіг ван Бетховен: “Для людини з талантом і любов’ю до праці не існує перешкод”. Суть проблеми полягає не стільки в тому, щоб надати однакові права особам різної статі, а насамперед, потрібно створити такі умови суспільного життя, щоб і жінка, і чоловік справді були спроможні ре-

\section{Список літератури}

1. Конституція України, ухвалена 28 червня 1996 року // Офіційний портал Верховної Ради. - http://rada. gov.ua/

2. Закон України “Про освіту” від 23.05.1991 р. № 1060-XII (редакція станом на 01.01.2015 p.). - zakon. rada.gov.ua

3. Закон України “Про вищу освіту” № 1556-VII (редакція станом на 01.07.2014 p.). - zakon.rada.gov.ua

4. Конвенція ООН "Про ліквідацію всіх форм дискримінації щодо жінок”, прийнята 34 сесією Гене- алізувати себе повноцінно як у громадському, професійному, так і в особистому житті.

Висновки. Отже, тема гендерної рівності у вищій освіті $є$ дуже важливою і маловивченою. У спеціальній літературі використовується термін “скляна стеля”, що означає бар’єр на шляху жінок до керівних посад та служить додатковим показником гендерної нерівності у різних сферах. Однак, яким би не було людське суспільство, воно складається з двох найбільших категорій людей: чоловіків і жінок. I в культурі кожного суспільства $є$ норми, моделі поведінки, традиції, які передаються від покоління до покоління, уявлення про те, якими повинні бути чоловіки та жінки, які соціальні ролі їм відігравати.

Для гармонійного розвитку нашого суспільства необхідно створити підгрунтя для оновлення та реформування сформованої системи на гуманітарних, ненасильницьких засадах і здійснити гендерну підготовку та перепідготовку керівних кадрів управлінського апарату відповідно до європейських засад відкритості аби не було жодної “скляної скелі” на шляху реалізації своїх прав та свобод і чоловіками, і жінками.

ральної Асамблеї ООН і відкрита для підписання 18 грудня 1979 року. - search.ligazakon.ua〉1_doc2.nsf/link1/ MU79K04R.html

5. Когут I. Гендерна (не)рівність у вищій освіті в цифрах і фактах / I. Когут. - http:education-ua.org/ua/ tsifri-i-fakti/332-genderna-ne-rivnist-u-vishchij-osviti-vtsifrakh-i-faktakh

Отримано 16.06.15 